\title{
Adolescent Reproductive Health \& Media Production Organization in Indonesia: Perspective Religion and Health
}

\author{
$1^{\text {st }}$ Fatma Sylvana Dewi Harahap ${ }^{1}$ \\ \{fatmasylvana@helvetia.ac.id ${ }^{1}$ \} \\ Institut Kesehatan Helvetia ${ }^{1}$
}

\begin{abstract}
The production organization in media practice Indonesia should not only entertaining or attractive but it should be packed with the contents of education and Islamic religious values which can be a preventive to reduce the incidence of unwanted pregnancies that will end by unsafe abortion in adolescents. Reintegrate and analyzing by philosophy (epistemology, axiology and ontology) on the dynamics of the science and religion application in the concept of adolescent reproductive health and da'wah through production organizations in the practice of media. Positive impact are reintegrate organization production of media and the philosophy of Islam will be born a media who will consume by country and Muslim that suitable for them especially a prevention of adolescent reproductive health. Media, education, and da'wah is one of steps in integration of religion and science to counteract the negative effects of media practice also relevant to prevent unwanted pregnancy and unsafe abortion.
\end{abstract}

Keywords: Adolescent reproductive health production organizations, media, science and religion

\section{Introduction}

Maternal death rate because of abortion which is the reason of unwanted pregnancy in the world has increase. It is estimate about $13 \%$ or 67.000 of death because of unsafe abortion practical which is happen in development country, one of them Indonesia.[1] Muslim woman as a user of media practice who are not married do their imagine for what they have see without used religion values has been misguided after become a media consumer who deserve by western without filter. According to them $70 \%-80 \%$ media can influence their daily behavior and applicate their imagination to know or just follow the trend.[2] The impact of this position is the increase of unwanted pregnancy in industry area which is end by unsafe abortion increase year by year.[3]

Muslim should develop their own film, industry video, music, and attractive art to the global audience and used western media facility and also to know how the channel of Islamic education for da'wah and education.[4] Global culture has move local culture behavior who protect reproductive health of adolescent. So, it will be better to back to media practice as a technology as a "son" of science back to the touch of Islamic philosophy who integrate religion and science in this case the religion and reproductive health of adolescent as a prevention, promotion, and therapy in counselling of reproductive health. 


\section{Method}

This research used analyzing with philosophy approach (epistemology, ontology, and axiology)[5] by integrate religion and science.

a. Reproductive health and religion in epistemology

If we build an epistemology reconstruction by used them as an exploration process to the holy book text as an epistemology process to get scientific conclusion so it will get the criteria of truth which is based on faith that whatever listed in Al-Quran and whatever state by prophet Muhammad certainly is the truth. This is called the theory of truth based on faith (faith theory of truth).

b. Reproductive health and religion in ontology

In line with human submission to the law of Allah hence the practice problem in solving all of the human problem at relate and step on fundament of religion metaphysics (Islam). The knowledge theory not just stop in theory but often enter to the practice area which is implementing them in a social system to solve all of the humanity problem. Therefore the way to solve the problem especially more than one alternative also have metaphysic element.

c. Reproductive health and religion in axiology

While science and technology have a secularization process and empty from the godness values, like western science generally, hence the final goal and benefit (naf'iah) is pleasure, beauty and safety and also intellectual satisfaction and pride. On the contrary when the godness values entering the science process it will result scientific theory that suitable to the Islamic comprehension which is also materialism.

\section{$3 \quad$ Research Finding}

\subsection{Production organization of media and concept of Islamic thought as an application form in integration of religion and adolescent reproductive health.}

Production organization as a technic and method to get the media quality that will serve to the audience. A solid teamwork needed to get the goal so it can be categorized as an industry who looking for a consumer to have pleasure the result thought that will give to the audience target. One of the goals is to persuade audience target in this case teenager, to invite them to introduce global culture besides possessed their blood cells that will replays local culture and also their religion values.[6]

According to the truth, there is no fault to learn about production organization in media practice who served by western. A benefit give for them are "something" which is have a quality with a hard work and great teamwork to consumer by management and technology. The problem is modern western managerial accept without filtrates. Azra state adopting the philosophy thought and theory without a good criticism and take them without process (raw) is not contextual and relevant with Islamic education because they are not education of Islamic thought it self.[7] This thought also in line with Nurkholis Majid statement that religion of Islam should be as a "grounds for meaning" or "the principle of life" with have an 
obedience an (point of view to solving a problem). [8] In integrated aspect, Bakar states an obsession to the science and technology by put aside moral values and spiritual which is held in high esteem is one of the big misfortune in this area. So Islam and Moslem important to create brilliant civilization based on spiritual and moral foundation.[9] In His holy book Allah State. ("You are the best nation or people of all humans; invites to good things, prevents morbidity and faith in Allah." Al-Quran 3:10)

If we explore deepest da'wah as a media in Islam is oriented by proving greatness of Allah by technical and methods that accept by logic. To support the statement of shari'a it needs an aligned with non shari'a that refer to the development of communication technology, because evidently the communication technology it is not just influence an aspect of life but almost all of joints of many aspect of community life.[10]

\subsection{Arrangement Impact of Production Organization of Persuade to Sacradness of Marriage}

The increase case of unwanted pregnancy as one of the cases in reproductive health as a factor of media. Let us say if a media even television, radio or newspaper will plan a production process who have a goal to persuade to influence an adolescent lifestyle. Then the media will review the audience profile until decide to put down budget to help them to applicate this plan until the stage of feedback. While i Muslim world more directly media as a tool of support dawah as an education and information as a one of goal choice in production organization.[11]

Elizabeth B. Hurlock states there are 3 sexual behavior factors in adolescent, they are development factor that happened to themselves, it comes from family where they growth and development. Second, external factor that is school or formal education that have enough to act for adolescent development to achieve their maturity. Third, public factor they are habit, association, and development in many aspect especially technology that achieved by human.[12]

What a disadvantage a generation of a nation if they left alone persuaded by negative impact of industry who have a goal to consume them all of the time by advantage of company and the loss of future for generation. That happened, so may case of unwanted pregnancy because of the factor of persuaded attractive show of media especially television. It is proved by Neuman who states everyday television shows 3.6000 image per minutes, radio approximately 100 words per minute and internet serve approximately 150.000 per days.[13]

At the downstream, adolescent will find a problem related with their reproductive health. Adolescent reproductive health becomes a marginalized group. They are not like a group of adolescent who have married. Adolescent almost don't have many accesses to the service of information and counselling of reproductive health. As a result so may adolescent have a problem of reproductive health in their young age as an infection of sexual/ HIV/AIDS or unwanted pregnancy.[14]

Many experts state one of resolve sexual behavior of adolescent is provide an information about reproductive health because of unavailable accurate and exact information about reproductive health, this condition force them to make exploration by themselves, even by information of media or friend. The other factor is to minimize information about free sex. In this case mass media and entertainment is very important.[15] 
Media practice, in this case production organization with their goal to persuade are very harmful to adolescent if they are lived all about the positive philosophy of live such values of religion and local wisdom. The reason is, if management of production organization nicely arrangement as an industry can trap the audience as a consumerism, materialism, materialism and exclusivism. The majority audience who have trap are teenager as a person who still looking for identity of life and still shows their existences.[15]

As a protection for adolescent are to change the reductive and partial paradigm of mind of science in this case reproductive health of adolescent by all the health knowledge including midwifery, medicine, nurse etc even though religion and dawah who state true and ambitious with their knowledge. The important one is work culture as a strategic step can have an orientation to public and ummah -in this case a generation- with "bil hikmah wal mauziah hasanah" approach, midwife and preacher as an agent by media user. The goals are to wake up muslimin, to educate their soul and equip up them by enough devotion to build their health soul and body.[16] So that we can produce and leave a heritage a health generation for a strong nation.

\subsection{Build up a sinergy of production organization with local wisdom, religion and education as an media typical identity of nation.}

When we watch a television impression that title "Upin Ipin" from neighbor country, there are so many moral massages build up from this series of this cartoon. What a life philosophy built from the character of their own country without leaves their culture and religion values as an identity besides also use production organization as a technic that will be a result from science and technology which is serve a creation with the terms of inspiring, wisdom, and philosophy without leave their religion values that sources from Al-Qur'an and Hadits and also local culture. So that this creation can be categorized to educate the audience. Isn't one of the functions of Al-Qur'an is human (Al-Baqarah 2:2), a point who gives a good orientation to a development civilization. A knowledge as a form of civilization which is develop by human also cannot escape from the touch of Al-Qur'an. In this place mukminin in the early history always guided by Al-Qur'an to protect and develop a true science.[17] A spectacle of television that loaded a religion values and culture have rarely find in television station in Indonesia especially for adolescent age so the impacts are negative sexual behavior because the media does not educate them. This is because of television manages in manner and arrange can lift social reality in many film, drama, telenovela and news. A power of television and public power accumulated in an extraordinary influence of television its elf. So that give an extraordinary impact for community hobbies also functionally it can be structured on them.[18]

A country sued on for revitalization of science to religion by give an attention to the wisdom of science over the overseas or military.[7] So the problem of this country can find an answer themselves and stand on their leg themselves including plan of science and technology in media and a secure production organization for now and future generation.

\section{Conclusion}

Production organization to produce a media is not a scared for Muslim countries. It is a methods and management how to build a media who have a quality and arrangement. 
Production organization if packed by western with religion concept will be born a creation who have an inspiring and tactful. It will be more attractive if a media born from Muslim countries that suitable with their countries, Islam and global so Islam will not be leave at all from the sophisticated technology of media and they can compete with the country's pioneer. Muslim can create a sophisticated technology of media with attractive, educative, informative in their own world and global by arrangement of production organization that integrate with religion values.

Reproductive health counselling which has been used so far by scientist like a midwife and other professional health that just rely a leaflet will be more interest for teenager or adolescent if they are packed by media which is used production organization by distributed them to the schools as a prevention of unwanted pregnancy. In curative level, midwife can give a counselling by use a media that attractive and unrestful as therapeutic communication for adolescent as a target audience who has a victim of negative media impact that persuade them and they will recovery from physics and psychology trauma a marginalized people.

The revitalization of religion and science need to develop to advance the step and thought to media that protect a consumer. Because if they just a consumer, we will always follow and agree to the thought what they have given, while it is not suitable if applicate them to the country and the citizen as a consumer. The struggle and jihad in dakwah that integrate with science and technology is to be struggle with a new aspect they are an information attract so it cannot be controlled by the information dominator. It is exactly with Bhakti states about communication elements, they are who says what, which channel, to whom, with what effect, and then how is it received.

\section{References}

[1] WHO, "Unsafe Abortion: Global and Regional Estimates of Incidence of Unsafe Abortion and Associated Mortality in 2000, 4th," Jenewa, 2004.

[2] S. Pranata and F. S. Sadewo, "Kejadian Keguguran, Kehamilan tidak Direncanakan dan Pengguguran di Indonesia," 2012.

[3] F. S. D. Harahap, "Reproductive Health Course and Index Interview Result with the Student of Midwifery Diploma," Tangerang Selatan, 2015.

[4] Bhakti and A. Faisal, "No TitleThe Role of Islamic Media in The Globalization Era: Between Religious Principles and Values of Globalization, The Challenges and Opportunities," Jakarta, 2015.

[5] Akbar, H. Usman, and P. Setiadi, Metodologi Penelitian Sosial. Jakarta: PT Bumi Aksara, 2009.

[6] G. Branston and R. Stafford, The Media Student's Book. .

[7] A. Azra, Pendidikan Islam: Tradisi dan Modernisasi Menuju Milenium Baru, dalam Pengantar Pendidikan Islam dan Kemajuan Sains: Refleksi Historis Menuju Milenium Baru. 1999.

[8] N. Majid, Bilik-bilik Pesantren: Sebuah Potret Perjalanan. Jakarta: Paramadina, 1997.

[9] O. Bakar, Tauhid dan Sains: Perspektif Islam tentang Agama dan Sains. Bandung: Pustaka Hidayah, 2008.

[10] F. Wahid, "Dakwah Melalui Internet," e-Dakwah. Gava Media, pp. 24-25.

[11] G. Branston and R. Stafford, The Media Student's Book. 2003.

[12] E. B. and Hurlock, Psikologi Perkembangan Suatu Pendekatan Sepanjang Rentang Kehidupan. Jakarata: Erlangga, 2004.

[13] W.Neuman Russell and et al., Common Knowledge, News on the Communication of Political Meaning, (Chicago: University of Chicago Press, 1992.

[14] Gulardi H.Wiknjosastra dkk, Kesehatan Reproduksi: Panduan Pengajar, Yayasan Pendidikan Kesehatan Perempuan. Jakarta: YPKP, 2004. 
[15] I. Kumalasari and I. Andhyantoro, Kesehatan Reproduksi. Jakarta: Salemba Medika, 2012.

[16] A. Muhammad and Ar-Rasyid, Khittah Dakwah. Jakarta: Robbani Press, 2005.

[17] D. Darmawan, Al-Qur'an dan Pengetahuan Ilmiah dalam Al-Qur'an dalam Arus Globalisasi dan Modernitas. Jakarta: LPSI, 2004.

[18] M. B. Bungin, Konstruksi Sosial Media Massa. Jakarta: Kencana, 2004. 